\title{
The spectrum of $\beta$-thalassemia mutations in the Arab populations
}

\author{
Laila Zahed ${ }^{\dagger}$ \\ Department of Pathology and Laboratory Medicine, American University of Beirut, Beirut, Lebanon
}

\begin{abstract}
The Arab countries encompass a wide region stretching from the Persian Gulf to the Atlantic Ocean. The Arab population is quite heterogeneous and has experienced various invasions and migrations throughout history. $\beta$-thalassemia is endemic in all countries of the Arab world. Our review of the molecular basis of $\beta$-thalassemia in various Arab countries reveals the presence of 52 mutations, which are mostly of Mediterranean and Asian origin. The distribution of mutations reflects the geographical and historical backgrounds of each region. However, no specific mutation is confined to the Arabs, although some Arab countries do have unique mutations.
\end{abstract}

\section{INTRODUCTION}

The Arab world is composed of 21 countries stretching from the Persian Gulf to the Atlantic Ocean. Although Arab people share a common history and culture, they are quite heterogeneous in origin, a fact that should be reflected in their genetic background. $\beta$-thalassemia is endemic in all countries of the Arab world, probably due to the presence of malaria previously in that region, and the frequency of carriers varies from $1 \%$ to $5 \%$. The molecular basis of $\beta$-thalassemia has been studied in various Arab countries and we present here a review of those findings, in an attempt to compare the frequency and origin of the different mutations.

\section{REVIEW OF THE LITERATURE}

Various papers reporting the spectrum of $\beta$-thalassemia mutations in different Arab countries have been published. While detailed information about many populations is available, data for some countries is still lacking or only preliminary. In some cases, the studies may be too small or too specific to represent the entire country. Still, as much of the currently available data have been collected and pooled and the reported mutations and their corresponding frequencies in twelve different countries have been tabulated for comparison (see Table 1). These include Syria [1], Lebanon [2-4], Jordan [5], Israeli Arabs [6] and Arabs from the Gaza strip [7], Saudi-Arabia [8-11], Kuwait [12], Bahrain [13], the United Arab Emirates (UAE) [14-17], Oman [18], Egypt [19-23], Tunisia [24, 25], and Algeria [26-28].

Arab countries from which data was not available included Djibouti, Iraq, Mauritania, Morocco, Qatar, Somalia, and Sudan. The data found on nationals from Lybia or Yemen, as part of larger studies, was based on a small number of patients in which only 2 or 3 of the most common Mediterranean mutations were detected. Since this was thought not to be clearly representative of the population of each of these countries, the data was omitted from this study.

\section{RESULTS}

A total of 52 mutations have been reported in the Arab world, reflecting the heterogeneity of its population. As expected, each country has its own characteristic spectrum of mutations, with a handful of frequent mutations and several rare ones. The number and frequency of different mutations varies from one country to another, depending on the studies and size of the population: total numbers reported so far vary from 9 in Kuwait to 21 in Egypt. While some mutations appear in most countries, others seem to be specific to a region or even a country. Several observations can be made, discussed here below.

(1) The common Mediterranean mutations were detected in nearly all Arab countries, albeit at different frequencies. Codon $39(\mathrm{C}>\mathrm{T})$, the most frequent mutation in the western Mediterranean region, was found in all Arab countries without exception. As expected, it is found at higher frequencies in more western Arab countries, such as Tunisia and Algeria (27\% in both), whereas eastern countries show much lower frequencies (down to $0.5 \%$ in Lebanon). Surprisingly, it also reaches high frequencies in some southeastern nonMediterranean countries, such as Saudi Arabia (20\%) and Bahrain (24\%). IVSI-110 (G>A) is the most common mutation in the eastern Mediterranean. It has high frequencies in all Mediterranean Arab countries (12\%-38\%), but reaches lower frequencies in countries around the Gulf $(0 \%-2 \%)$. The same is true for IVSI-1 $(\mathrm{G}>\mathrm{A})$ and IVSI- 6 (T>C), two other frequent Mediterranean mutations. On the other hand, IVSII$1(\mathrm{G}>\mathrm{A})$, was detected in all countries except Tunisia and Algeria, has a high frequency in North Jordan (20\%) and is the 
TABle 1: Comparison of mutation frequencies among 13 Arab populations. ( $\mathrm{S}=$ Syria, $\mathrm{L}=$ Lebanon, $\mathrm{J}=\mathrm{Jordan}, \mathrm{IA}=\mathrm{Israeli}$ Arabs, $\mathrm{G}=\mathrm{Gaza}$ strip, $\mathrm{SA}=$ Saudi Arabia, $\mathrm{K}=$ Kuwait, $\mathrm{B}=$ Bahrein, $\mathrm{UAE}=$ United Arab Emirates, $\mathrm{O}=$ Oman, $\mathrm{E}=\mathrm{Egypt}, \mathrm{T}=\mathrm{Tunisia}$, $\mathrm{A}=\mathrm{Algeria}$.)

\begin{tabular}{|c|c|c|c|c|c|c|c|c|c|c|c|c|c|c|}
\hline Mutation & Origin & $S$ & $\mathrm{~L}$ & $\mathrm{~J}$ & IA & G & SA & $\mathrm{K}$ & $\mathrm{B}$ & UAE & $\mathrm{O}$ & $\mathrm{E}$ & $\mathrm{T}$ & A \\
\hline IVSI-110 (G>A) & East Med & 24 & 33 & 22 & 26.4 & 37.5 & 22 & - & 1.5 & 1.7 & 0.5 & 33 & 12.3 & 24.7 \\
\hline IVSI-1 (G>A) & Med & 17 & 15 & 6.6 & 8 & 20 & 7 & 7.3 & 3 & - & 1 & 11.3 & 0.9 & 11.7 \\
\hline $\mathrm{Cd} 5(-\mathrm{CT})$ & Med & 8.5 & 4 & 3.3 & 0.64 & 10 & - & - & - & 4 & 0.5 & 2.4 & 1.8 & - \\
\hline$-30(\mathrm{~T}>\mathrm{A})$ & Turkish & 7 & 0.5 & - & 0.64 & - & - & - & - & - & - & - & 2.6 & 0.4 \\
\hline $\mathrm{Cd} 39(\mathrm{C}>\mathrm{T})$ & West Med & 6.4 & 0.5 & 2 & 8 & 11.5 & 20 & 7.3 & 24.2 & 5 & 1 & 1.5 & 27 & 27.6 \\
\hline IVSI-6 (T>C) & West Med & 4 & 15 & 6.6 & 14.7 & 7.5 & 7 & 7.3 & - & 3.5 & - & 13.6 & 6 & 3.3 \\
\hline IVSII-1 (G>A) & Med & 4 & 10 & 19.8 & 7 & 1 & 15 & 29 & 6.1 & 3.3 & 3.5 & 3 & - & - \\
\hline $\mathrm{Cd} 15(\mathrm{G}>\mathrm{A})$ & Asian-Ind & 3.5 & - & - & 0.64 & - & - & - & 1.5 & 1.5 & 0.5 & - & - & - \\
\hline$-88(\mathrm{C}>\mathrm{T})$ & Asian-Ind & 2 & 1.5 & - & - & - & - & - & - & - & - & - & 一 & - \\
\hline$-87(\mathrm{C}>\mathrm{G})$ & Med & 2 & 1.5 & 2 & - & - & - & - & - & - & - & 1.2 & - & - \\
\hline IVSI-116 (T>G) & Med & 1.4 & - & - & - & - & - & - & - & - & - & - & - & - \\
\hline IVSII-745 (C>G) & Med & 1.4 & 1 & 12 & 6 & - & - & - & - & - & - & 5.6 & 4.4 & 0.9 \\
\hline $\mathrm{Cd} 8 / 9(+\mathrm{G})$ & Asian-Ind & 1.4 & 0.5 & - & - & - & 2.5 & 1.3 & 1.5 & 7 & - & 0.3 & - & - \\
\hline $\mathrm{Cd} 37(\mathrm{G}>\mathrm{A})$ & Saud, Egypt & 1.4 & - & 8.8 & 7.4 & 1 & - & - & - & 1 & - & 0.6 & - & - \\
\hline $\mathrm{Cd} 8(-\mathrm{AA})$ & Turkish & 0.7 & 2.5 & - & 6 & 一 & 10 & 3 & - & 4 & - & 1.8 & 0.9 & - \\
\hline 25 bp deletion & Asian-Ind & 0.7 & 1 & - & - & - & 14 & 7.3 & 36 & 8 & 5.5 & - & - & - \\
\hline $\mathrm{Cd} 29(\mathrm{C}>\mathrm{T})$ & Lebanese & - & 7 & - & - & - & - & - & - & - & - & - & - & - \\
\hline $\mathrm{Cd} 30(\mathrm{G}>\mathrm{C})$ & UAE & - & 3 & - & - & - & - & - & - & 3 & - & - & - & - \\
\hline 290 bp deletion & Turk, Iran & - & 2 & - & - & - & - & - & - & - & - & - & - & - \\
\hline $\mathrm{Cd} 44(-\mathrm{C})$ & Kurdish & - & 1 & - & - & - & 7.5 & 1 & 4.5 & 1.3 & 9.6 & - & 4.4 & - \\
\hline IVSI-5 (G>C) & Asian-Ind & - & 0.5 & 5.5 & 2.6 & - & 10 & 18.8 & 16.7 & 55 & 61.6 & - & - & 0.4 \\
\hline $\mathrm{Cd} 27(\mathrm{G}>\mathrm{T})$ & Med & - & - & 3.3 & - & 1 & - & - & - & - & - & 0.3 & 0.9 & 0.4 \\
\hline IVSII-848 (C>A) & Egyptian & - & - & 2 & - & - & - & - & - & 0.5 & - & 8.6 & 0.9 & 0.4 \\
\hline $\mathrm{Cd} 6(-\mathrm{A})$ & Med & - & - & 1 & - & 5 & 7 & - & - & - & - & 1 & 10.5 & 17 \\
\hline IVSII-3' (C>A) & Black & - & - & - & 0.32 & - & - & - & - & - & - & - & - & - \\
\hline AATAAA $>$ A & Arab & - & - & - & - & 2.5 & - & - & - & - & - & - & - & - \\
\hline IVSI-5 (G>T) & Med & - & - & - & - & - & 2 & - & - & - & - & - & - & - \\
\hline Cap +1 (A>C) & Asian-Ind & - & - & - & - & - & 1 & - & - & - & - & 0.6 & - & - \\
\hline $\mathrm{Cd} 36 / 37(-\mathrm{T})$ & Kurd, Iran & - & - & - & - & - & 11.5 & - & - & 0.4 & 1 & - & - & - \\
\hline$-88(\mathrm{C}>\mathrm{A})$ & Kurdish & - & - & - & - & - & - & - & 1.5 & - & - & 0.6 & - & - \\
\hline $\mathrm{Cd} 35(-\mathrm{C})$ & Indonesian & - & - & - & - & - & - & - & 1.5 & - & - & - & - & - \\
\hline Cd41/42 (-TCTT) & Asian-Ind & - & - & - & - & - & - & - & 1.5 & - & - & - & - & - \\
\hline $\mathrm{Cd} 82 / 83(-\mathrm{G})$ & Azerbaijian & - & - & - & - & - & - & - & - & 1 & - & - & - & - \\
\hline $\mathrm{Cd} 37(-\mathrm{G})$ & Kurdish & - & - & - & - & - & - & - & - & 1 & 0.5 & - & - & - \\
\hline AATAAA $>$ AATAAG & Kurdish & - & - & - & - & - & - & - & - & 0.8 & - & - & - & - \\
\hline $\mathrm{Cd} 110(\mathrm{~T}>\mathrm{C})$ & Japanese & - & - & - & - & - & - & - & - & 0.8 & - & - & - & - \\
\hline$-101(\mathrm{C}>\mathrm{T})$ & Turkish & - & - & - & - & - & - & - & - & 0.8 & - & - & - & - \\
\hline $\mathrm{Cd} 30(\mathrm{AGG}>\mathrm{AGC})$ & various & - & - & - & - & - & - & - & - & 0.4 & - & - & - & - \\
\hline $\mathrm{Cd} 30(\mathrm{G}>\mathrm{A})$ & Bulgarian & - & - & - & - & - & - & - & - & - & 0.5 & - & 2.6 & 0.9 \\
\hline Hb Dofar & Omani & - & - & - & - & - & - & - & - & - & 6.6 & - & - & - \\
\hline 619 bp deletion & Indian & - & - & - & - & - & - & - & - & - & 4 & - & - & - \\
\hline $\mathrm{HbE}$ & Asian-Ind & - & - & - & - & - & - & - & - & - & 0.5 & - & - & - \\
\hline $\mathrm{Cd} 29(-\mathrm{G})$ & Japanese & - & - & - & - & - & - & - & - & - & - & 1.2 & - & - \\
\hline $\mathrm{Cd} 106 / 107(+\mathrm{G})$ & Black & - & - & - & - & - & - & - & - & - & - & 0.6 & - & - \\
\hline $\mathrm{Cd} 28(-\mathrm{C})$ & Egypt & - & - & - & - & - & - & - & - & - & - & 0.3 & - & - \\
\hline $\mathrm{Cd} 25 / 26(+\mathrm{T})$ & Tunisian & - & - & - & - & - & - & - & - & - & - & - & 0.9 & - \\
\hline IVSI-2 (T>A) & Algerian & - & - & - & - & - & - & - & - & - & - & - & 0.9 & 1.3 \\
\hline IVSI-5 (G>A) & Algerian & - & - & - & - & - & - & - & - & - & - & - & 0.9 & 0.9 \\
\hline$-29(\mathrm{~A}>\mathrm{C})$ & Black & - & - & - & - & - & - & - & - & - & - & - & - & 3.8 \\
\hline IVSI-2 (T>C) & Black & - & - & - & - & - & - & - & - & - & - & - & - & 3.3 \\
\hline IVSII-843 (T>G) & Algerian & - & 一 & 一 & - & - & - & - & - & - & - & - & - & 0.4 \\
\hline \multicolumn{2}{|c|}{ Total mutations } & 16 & 18 & 13 & 13 & 10 & 14 & 9 & 12 & 21 & 15 & 19 & 16 & 16 \\
\hline
\end{tabular}


most common mutation in Kuwait (29\%). Codon 5 (-CT), a Mediterranean mutation of lower frequency, was found in all Arab Mediterranean countries, except Algeria, while it was not detected in most countries of the Arabian Peninsula.

(2) The G>C substitution at IVSI-5, a mutation of AsianIndian origin, is the most common mutation in the UAE (55\%) and Oman (62\%), and is quite frequent in neighboring Kuwait and Saudi Arabia (17\%-19\%). It is also found in the majority of other Arab countries, although its frequency diminishes appreciably in countries of Northern Africa.

(3) A handful of mutations are found at low frequencies in over half of the countries studied. These include IVSII-745 $(\mathrm{C}>\mathrm{G})$, a mutation of Mediterranean origin, detected solely in Mediterranean Arab countries, and found at its highest frequency in North Jordan (12\%); Cd6 (-A), another Mediterranean mutation found mostly in North African Arab countries $(10 \%-17 \%)$ and at a lower frequency in Gaza and Saudi Arabia. Cd8 (-AA) is a mutation of Turkish origin found at more or less the same low frequency, except in Saudi Arabia, where it reaches 10\%. Two Asian-Indian mutations, Cd8/9 $(+\mathrm{G})$ and the $25 \mathrm{bp}$ deletion are found at low frequency in some countries but reach their highest frequencies in countries of the Arabian Peninsula. In fact, the $25 \mathrm{bp}$ deletion is the most frequent mutation in Bahrain (36\%). Cd44 (-C) is a mutation of Kurdish origin detected mostly in countries of the Arabian Peninsula (up to $10 \%$ in Oman), but also in Lebanon (1\%) and Tunisia (4\%). Cd37 $(\mathrm{G}>\mathrm{A})$ is a mutation mostly encountered in Jordan (9\%) and among Israeli Arabs (7\%).

(4) Six mutations were detected in more than two Arab countries. These include the $\mathrm{T}>\mathrm{A}$ substitution at -30 , a mutation of Turkish origin, detected only in Mediterranean Arab countries, Cd15 (G>A), an Asian Indian mutation, clustered around countries of the Gulf, but also found in Syria and Israeli Arabs; the substitution at $-87(\mathrm{C}>\mathrm{G})$ is of Mediterranean origin and thus found in 4 mediterranean countries. Cd27 (C>T) and IVSII-848 $(\mathrm{C}>\mathrm{A})$ are found mostly in Northern African Arab countries, with some patients reported in Jordan. $\mathrm{Cd} 27$ is also known as $\mathrm{Hb}$ Knossos, reported around the Mediterranean, while IVSII-848 is of Egyptian origin, which explains its highest frequency there (9\%). The frameshift mutation at $\mathrm{Cd} 36 / 37(-\mathrm{T})$ is reported only from countries in the Arabian Peninsula. This Kurdish/Iranian mutation is quite frequent in Saudi Arabia, where it represents $12 \%$ of the alleles studied. The substitution at $\mathrm{Cd} 30(\mathrm{G}>\mathrm{A})$ is reportedly of Bulgarian origin and was detected mostly in Tunisia and Algeria (1\%-3\%).

(5) Some rare mutations were reported in two countries, which generally tend to be neighboring countries. This is true of $-88(\mathrm{C}>\mathrm{T})$, a mutation of Asian-Indian origin, reported in Syria and Lebanon, Cd37 $(-\mathrm{G})$, of Kurdish origin, reported in Oman and the UAE, IVSI-2 (T>A) and IVSI-5 (G>A), both of Algerian origin, reported in Tunisia and Algeria. An AsianIndian mutation, Cap $+1(\mathrm{~A}>\mathrm{C})$ and a Kurdish mutation, $-88(\mathrm{C}>\mathrm{A})$ were both reported from a country in the Arabian Peninsula and Egypt. Cd30 (G>C), of UAE origin, was also detected at the same frequency in Lebanon (3\%).
(6) Some mutations were exclusively detected in one Arab country. Some of these are believed to have originated specifically there, while others have been previously reported at higher frequencies in other countries. In the first case, one can notably mention the Lebanese mutation, Cd29 (C>T) found in $7 \%$ of alleles; a 6 bp deletion in the poly-A tail, detected in the population of the Gaza strip; and $\mathrm{Hb}$ Dofar, detected in $7 \%$ of the alleles studied in Oman. Six other mutations have an exclusive origin in their reported country, and have, so far, not been identified elsewhere. Other mutations, although identified in a single Arab country, were previously seen in other populations. These include, for instance, the $290 \mathrm{bp}$ deletion of Iranian/Turkish origin, representing $2 \%$ of alleles in Lebanon; Cd35 (-C) of Indonesian origin and $\mathrm{Cd} 41 / 42$ (-TCTT) of Asian-Indian origin reported in Bahrain (1.5\% both); Cd110 (T>C) of Japanese origin, found in the UAE (0.8\%); the 619 bp deletion of Indian origin, reported in $4 \%$ of alleles in Oman; Cd106/107 $(+\mathrm{G})$, a mutation of Black American origin, identified in Egypt and -29 $(\mathrm{A}>\mathrm{C})$, another Black American mutation detected in Algeria only.

\section{DISCUSSION}

The Arab countries encompass a wide region including Northern Africa, the Nile valley, Western Asia and the Arabian Peninsula. In addition to geographic differences, each country has experienced admixtures from various populations throughout history. Furthermore, migration between Arab countries has been common until the present times. The heterogeneity of the Arab people is reflected in the $52 \beta$ thalassemia mutations detected. These mutations are mainly of Mediterranean and Asian origin, and, although some countries have unique mutations, no specific mutation seems to be confined to the Arabs.

The most widespread and common mutations are presumably the oldest. This is true of Codon 39 and IVSI-110. Cd39, which is believed to be of Roman origin, is most frequent in the Western Mediterranean Arab countries and decreases in frequency towards the East. However, this mutation also reaches a high frequency in some countries of the Arabian Peninsula, a fact that may be explained by gene flow and founder effect. IVSI-110, which is believed to have arisen in Turkey, reaches its highest frequencies in the Eastern Mediterranean Arab countries, and may have been introduced to other countries by a variety of settlers from the East, including Turks, Greeks, or Phoenicians.

The most frequent and widespread Asian-Indian mutation in Arab countries is IVSI-5 (G>C). As expected, its frequency is highest in countries of the Arabian Peninsula, while its lower frequency in Western Asian Arab countries may be explained by migration. This mutation is practically nonexistent in Northern Africa. However, the mutation in Arabs is found on a $\beta$-globin haplotype distinct from the Asian-Indian one, and is therefore believed to have an independent origin.

In general, the distribution of the other mutations, as expected, reflects the geographical location of each coun- 
try. Mutations of Mediterranean origin tend to be found at higher frequencies around the Mediterranean Arab countries, whereas Asian-Indian mutations tend to be clustered around countries closer to the Indian subcontinent. However, population migration may explain the flow of some of these mutations towards other distant countries. The same applies for some rare mutations: Arab countries of Northern Africa also have an admixture of some African Black mutations, while some Kurdish or Iranian mutations are often detected in countries of the Arabian Peninsula and Western Asia. In each country, the spectrum of mutations could be well explained by looking at its geographical location and its individual history of wars, invasions, migrations, and settlements.

\section{REFERENCES}

[1] Kyriacou K, Al-Quobaili F, Pavlou E, Christopoulos G, Ioannou $\mathrm{P}$, Kleanthous M. Molecular characterization of $\beta$-thalassemia in Syria. Hemoglobin. 2000;24:1-13.

[2] Chehab FF, Der Kaloustian V, Khouri FP, Deeb SS, Kan YW. The molecular basis of $\beta$-thalassemia in Lebanon: application to prenatal diagnosis. Blood. 1987;69:11411145 .

[3] Zahed L, Talhouk R, Saleh M, Abou-Jaoudeh R, Fisher C, Old J. The spectrum of beta-thalassemia mutations in Lebanon. Hum Hered. 1997;47:241-249.

[4] Zahed L, Qatanani M, Nabulsi M, Taher A. $\beta$ thalassemia mutations and haplotype analysis in Lebanon. Hemoglobin. 2000;24:269-276.

[5] Sadiq MFG, Huisman THJ. Molecular characterization of $\beta$-thalassemia in North Jordan. Hemoglobin. 1994;18:325-332.

[6] Filon D, Oron V, Krichveski S, et al. Diversity of $\beta$-globin mutations in Israeli ethnic groups reflects recent historic events. Am J Hum Genet. 1994;54:836-843.

[7] Filon D, Oron V, Shawa R, et al. Spectrum of $\beta$ thalassemia mutations in the Gaza area. Hum Mutat. 1995;5:351-353.

[8] Hasounah FH, Sejeny SA, Omer JA, Old JM, Oliver RWA. Spectrum of $\beta$-thalassemia mutations in the population of Saudi Arabia. Hum Hered. 1995;45:231-234.

[9] El-Hazmy MAF, Al-Swailem AR, Warsy AS. Molecular defects in beta-thalassemia in the population of Saudi Arabia. Hum Hered. 1995;45:278-285.

[10] Adekile AD. Historical and anthropological correlates of $\beta^{s}$ haplotypes and $\alpha$ and $\beta$-thalassemia alleles in the Arabian Peninsula. Hemoglobin. 1997;21:281-296.

[11] El-Harith E, Kuhnan W, Schmidtke J, Stuhrmann M, Nasserallah Z, Al-Shari A. Identification and clinical presentation of $\beta$-thalassemia mutations in the eastern region of Saudi Arabia. J Med Genet. 1999;36:935-937.

[12] Adekile AD, Gu LH, Baysal E, et al. Molecular characterization of alpha thalassemia determinants, betathalassemia alleles and beta $S$ haplotypes among Kuwaiti Arabs. Acta Haematol. 1994;92:176-181.

[13] Jassim N, Merghoub T, Pascaud O, et al. Molecular basis of $\beta$-thalassemia in Bahrein. Ann NY Acad Sci.
1998;850:407-409.

[14] El-Kalla S, Mathews AR. Molecular characterization of $\beta$-thalassemia in the United Arab Emirates. Hemoglobin. 1993; 17:355-362.

[15] Quaife R, Al-Gazali L, Abbes S, et al. The spectrum of $\beta$ thalassemia mutations in the UAE national population. J Med Genet. 1994;31:59-61.

[16] De Leo R, Deidda G, Novelletto A, El-Kalla S, Mathews AR, Felicetti L. Analysis of $\beta$-thalassemia mutations in the United Arab Emirates provides evidence for recurrent origin of the IVSI nt 5 (G-C) mutation. Hum Mutat. 1995;5:327-328.

[17] El-Kalla S, Mathews AR. A significant $\beta$-thalassemia heterogeneity in the United Arab Emirates. Hemoglobin. 1997;21:237-247.

[18] Daar S, Hussein HM, Merghoub T, Krishnamoorthy R. Spectrum of $\beta$-thalassemia mutations in Oman. Ann NY Acad Sci. 1998;850:404-406.

[19] Noveletto A, Hafez M, Deidda G, et al. Molecular characterization of $\beta$-thalassemia mutations in Egypt. Hum Genet. 1990;85:272-274.

[20] Hussein IR, Temtamy SA, El-Beshlawy A, et al. Molecular characterization of $\beta$-thalassemia in Egyptians. Hum Mutat. 1993;2:48-52.

[21] El-Hashemite N, Petrou M, Khalifa AS, et al. Identification of novel Asian Indian and Japanese mutations causing $\beta$-thalassemia in Egyptians. Hum Genet. 1997;99:271-274.

[22] Rady MS, Baffico M, Khalifa AS, et al. Identification of Mediterranean $\beta$-thalassemia mutations by reverse dotblot in Italians and Egyptians. Hemoglobin. 1997;21:5969.

[23] Waye JS, Borys S, Eng B, et al. Spectrum of $\beta$-thalassemia mutations in Egypt. Hemoglobin. 1999;23:255-261.

[24] Chibani J, Vidaud M, Duquesnoy P, et al. The peculiar spectrum of $\beta$-thalassemia genes in Tunisia. Hum Genet. 1998;78:190-192.

[25] Fattoum S, Guemira F, Oner C, et al. $\beta$-thalassemia and sickle cell anemia among Tunisians. Hemoglobin. 1991;15:11-21.

[26] Bennani C, Tamouza R, Rouabhi F, et al. The spectrum of $\beta$-thalassemia in Algeria: possible origins of the molecular heterogeneity and a tentative diagnostic strategy. $\mathrm{Br}$ J Haematol. 1993;84:335-337.

[27] Bennani C, Bouhass R, Perrin-Pecontal P, et al. Anthropological approach to the heterogeneity of $\beta$ thalassemia mutations in Northern Africa. Hum Biol. 1994;66:369-382.

[28] Bouhass R, Perrin P, Trabuchet G. The spectrum of $\beta$ thalassemia mutations in the Oran region of Algeria. Hemoglobin. 1994;18:211-219.

\footnotetext{
† E-mail: 1ai 1az@aub.edu. 1b

Fax: +961 1744 464; Tel: +961 1350000
} 

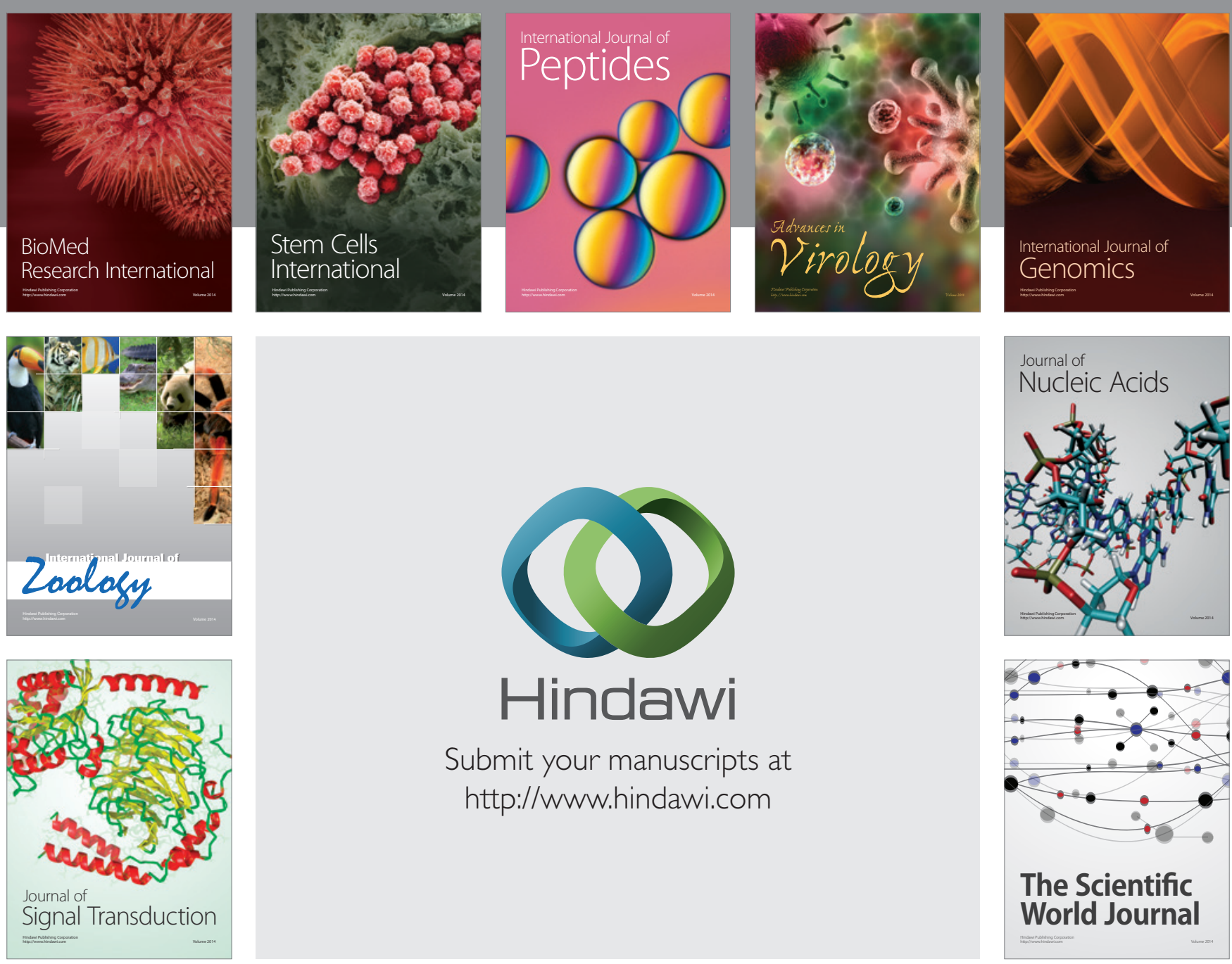

Submit your manuscripts at

http://www.hindawi.com
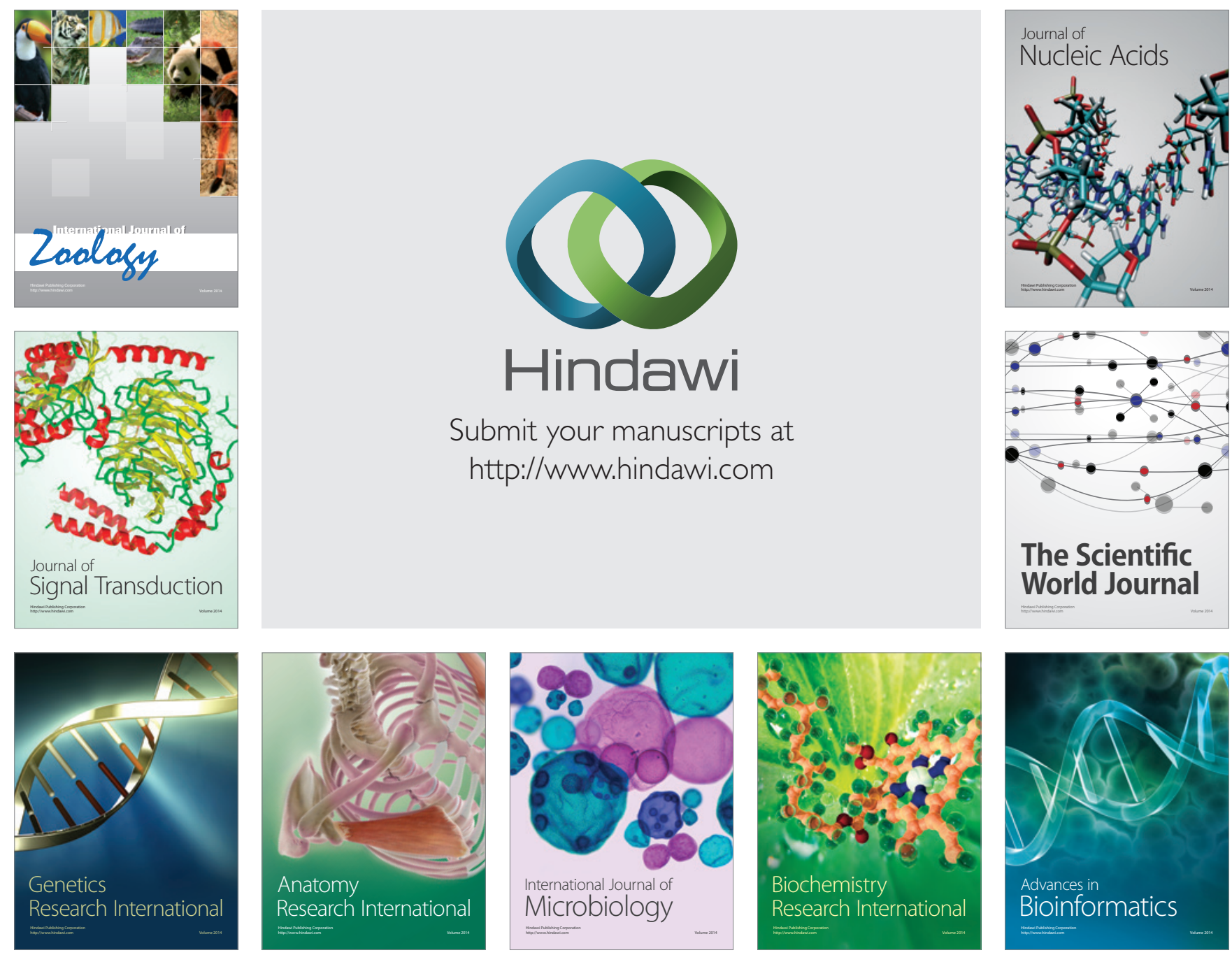

The Scientific World Journal
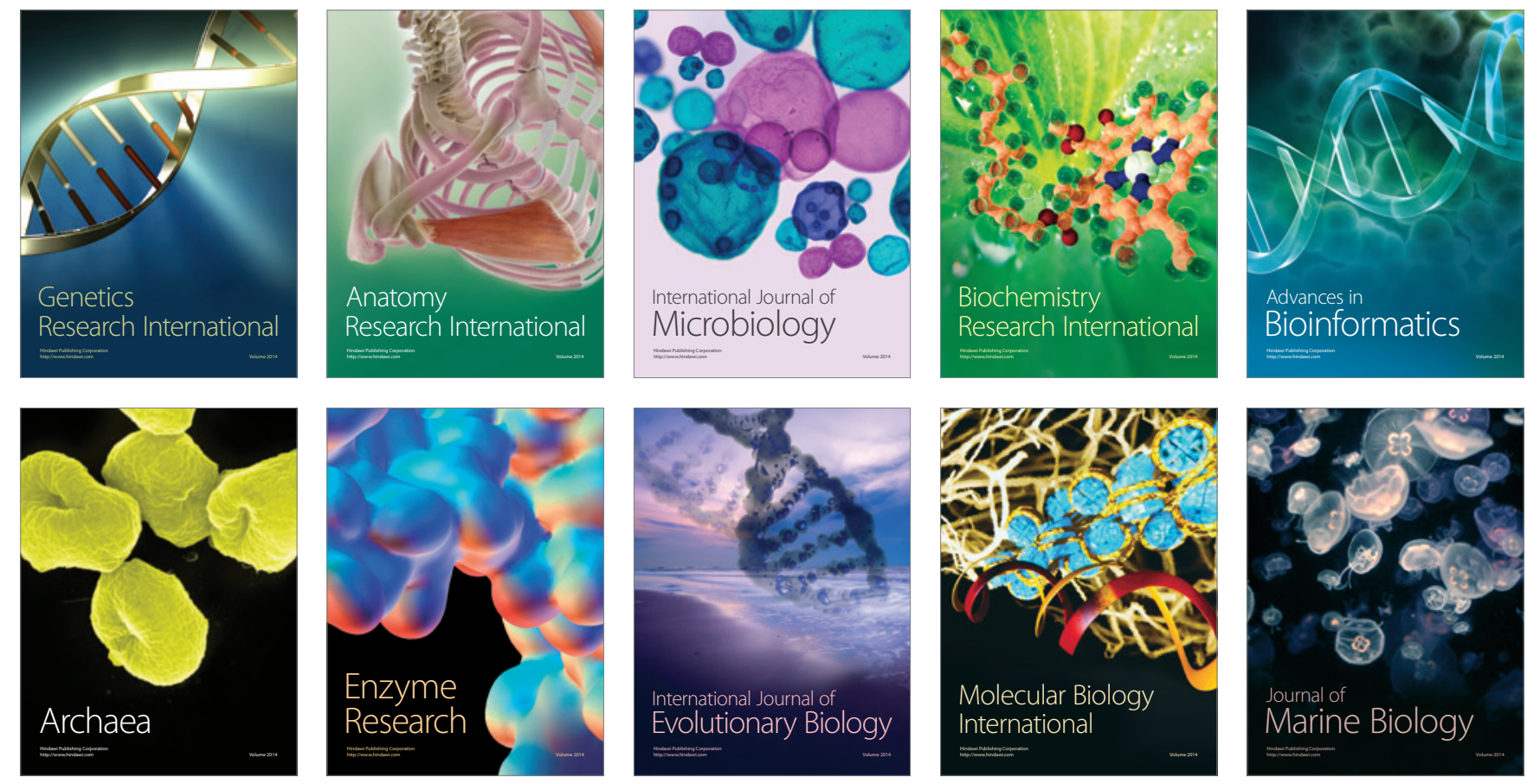